\title{
THE MAKASSAR ANNALS
}


The Bibliotheca Indonesica is a series published by the Koninklijk Instituut voor Taal-, Land- en Volkenkunde (Royal Netherlands Institute of Southeast Asian and Caribbean Studies), Leiden. The series contains critical editions of texts in various Indonesian languages, together with a translation and commentary in English. 


\author{
BIBLIOTHECA INDONESICA \\ published by the \\ KONINKLIJK INSTITUUT \\ VOOR TAAL-, LAND- EN VOLKENKUNDE \\ 35

\section{THE MAKASSAR ANNALS} \\ translated and edited by \\ WILLIAM CUMMINGS
}

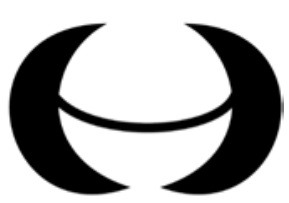

KITLV Press

Leiden

2010 
Published by:

KITLV Press

Koninklijk Instituut voor Taal-, Land- en Volkenkunde

(Royal Netherlands Institute of Southeast Asian and Caribbean Studies)

P.O. Box 9515

2300 RA Leiden

The Netherlands

website: www.kitlv.nl

e-mail: kitlvpress@kitlv.nl

KITLV is an institute of the Royal Netherlands Academy of Arts and Sciences (KNAW)

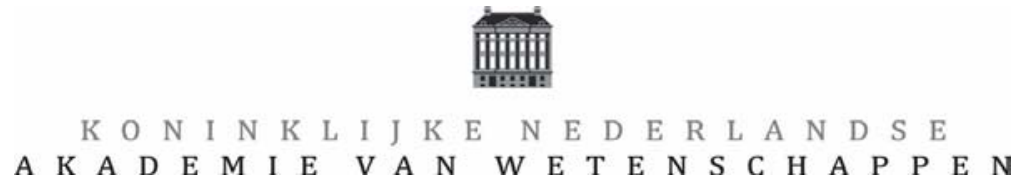

Cover: Creja ontwerpen, Leiderdorp

Cover photo: Gowa's main mosque, c. 1925 (KITLV 34239)

ISBN 9789067183666

KITLV Press applies the Creative Commons Attribution-NonCommercialNoDerivs 3.0 Unported License (http://creativecommons.org/licenses/by-ncnd/3.0/) to selected books, published in or after January 2011.

Authors retain ownership of the copyright, but they permit anyone unrestricted use and distribution within the terms of this license.

Printed editions manufactured in the Netherlands 


\section{Contents}

Preface vi vi v v

Abbreviations $\quad$ viii

I Introduction 1

II The annals; Transliteration, translation, and notes 33

$\begin{array}{ll}\text { III A further annals; ANRI 16/6 } & 307\end{array}$

IV Index of personal names 313

Glossary 349

Reigns lists for the rulers of Gowa and Talloq 351

$\begin{array}{ll}\text { Bibliography } & 355\end{array}$

$\begin{array}{ll}\text { Index } & 357\end{array}$ 
William Cummings - 9789004253629

Downloaded from Brill.com@4/26/2023 01:46:50PM via free access 


\section{Preface}

Beginning in perhaps the 1630s, a series of annalists at the main courts of Makassar began keeping a novel form of historical record. Lontaraq bilang, or 'counting manuscripts', contained carefully dated and chronologically ordered entries recording significant or surprising events. They were a clear departure in form and function from the genealogically-structured chronicles being composed about the ruling families of Gowa and Talloq in the same era. Most significant, perhaps, whereas Makassarese chroniclers ceased their work with (or at least by the time of) the conquest of Gowa and Talloq by the Dutch East India Company (VOC) and their Bugis allies in the 1660s, the annalists continued to make entries in their manuscripts. The Makassarese annals translated here continue unabated until the close of 1751. Moreover, the genre itself flourished in South Sulawesi and similar annals became a common form of record keeping among Makassarese and Bugis into the twentieth century.

The greatest obstacle to historical investigations into the events and dynamics of premodern Southeast Asia has long been the availability of sources. Manuscripts are too few, and too subject to the vagaries of chance and the depredations of a harsh tropical climate. Often we have little more than the impressionistic or inconsistent observations of European voyagers whose descriptions of Southeast Asian shores yield frustration at unasked questions as often as they do kernels of insight. The Makassar annals are a welcome refuge for historians accustomed to working with fragments like so many scattered tea leaves. Over the course of nearly a century and a half a series of annalists recorded 2360 entries - an average of 19.1 entries per year beginning in 1631. Moreover, these entries are carefully dated and the vast majority appear factually accurate as well as chronologically precise.

A textual lode of 2360 historical entries describing seventeenth and eighteenth-century events is a rare and precious resource for scholars of Southeast Asia. This translation is an invitation to scholars to use this rich resource in as many ways as possible to shed light on a fascinating part of the Indonesian archipelago. There are many possibilities here whether our interest is in biographical accounts of nobles and notables, the scaffolding 
of significant events to write narrative accounts of Makassarese and early colonial history, prosopographical analysis of distinct social groups and their dynamics over time, quantitative studies of entries to answer demographic questions, or any other approach to the multitude of subjects that captured the attention of generations of annalists at the courts of Makassar. We have an opportunity to repay their diligent efforts with our own.

My labors in translating and analyzing the lontaraq bilang have been considerably eased by friends, colleagues, and family. I owe Michael Decker for a thousand espressos, and John Belohlavek for nearly that many glasses of wine. Such friends make the solitary work of pondering and puzzling archaic historical entries bearable. Campbell Macknight and Anthony Jukes offered suggestions on this manuscript at different stages, no doubt too few of which I have followed. I would also like to express my ongoing appreciation to my teachers at the University of Hawai'i: Leonard Andaya, Barbara Watson Andaya, and Robert Van Niel. Portions of the Introduction were previously published in the Journal of Southeast Asian Studies and Bijdragen tot de Taal-, Land-en Volkenkunde. I owe a great debt to my Makassarese tutor, the late Djohan Daeng Salengke. Maile and Sophie were also much in my thoughts as this project came to fruition. My greatest obligation and thanks, however, belong to Sharon. How someone who can make all this seem so irrelevant and yet still encourage me is a wonderful mystery I have yet to fully untangle. 


\title{
Abbreviations
}

\author{
ANRI Arsip Nasional Republik Indonesia \\ NBG Nederlandsch Bijbel Genootschap \\ VOC Vereenigde Oost-Indische Compagnie \\ VT Miscellaneous languages collection [Verschillende Talen], \\ Perpustakaan Nasional Republik Indonesia, Jakarta
}

